ICHEU 2021

International Conference «Humanity in the Era of Uncertainty»

\title{
CROSS-CULTURAL ANALYSIS OF INTEREST TO ECONOMY IN CONTEXT OF CORONAVIRUS PANDEMIC
}

\author{
Julietta Albertovna Kitova (a)* \\ *Corresponding author \\ (a) Institute of Psychology of the Russian Academy of Sciences, 129366, Iaroslavskaia, 13, Building 1, Moscow, \\ Russia, j-kitova@yandex.ru
}

\begin{abstract}
It is assumed that in the condition of a pandemic, there will be an increased interest to economic factors of life among search system users, inevitably reflected in the nature of Internet search queries. Analysis of structural and content characteristics and dynamics of economy-related Internet queries in the context of pandemics covered three countries characterized with different historical and psychological types of economic development (Russia, USA and Japan). The research revealed that in all three countries queries with the word 'economy' are super popular, but the nature of interest varies between countries: in Russia, the interest to the economy has an abstract theorizing nature (the top result is "economy of the native land"), while in Japan and the USA, the interest is focusing on the effects of the COVID-19 pandemic on the economy. So, in the USA and Japan, all 15 leading economy-related queries are pandemic-related. Among the Russians, the influence of the pandemic onto the economy is interesting to some degree to mere $5 \%$ of the Russian users. In order to study the economy-related queries in more depth, statistics of queries from the Yandex Search was additionally studied. The queried terms reflect topics studied in schools, colleges and universities. All in all, it is possible to state that the interest to day-to-day economic activity is clearly underrepresented in popular queries in general, and this trend is preserved during the pandemic.
\end{abstract}

2357-1330 @ 2021 Published by European Publisher.

Keywords: Interest to economy, cross-cultural features, user queries, COVID-19 pandemic, crisis response measures 


\section{Introduction}

Studies of economic features of human development started expanding in 1980s and have not lost their pressing nature ever since (Fukuyama, 2004; Inglehart \& Welzel, 2005; Zhuravlev, 1998). Among topical works by Russian psychologist it is possible to point at such large topics of studies as economic features of the Russian culture, psychology of managerial decision-making, features of Russian consumer behavior and trends in economic socialization of youth among others. Within the frameworks of these research directions, Russian researchers conducted numerous particular studies that formed a foundation of the Russian economic psychology: economic settings, mutual relations between attitudes and economic behavior, perception of wealth and poverty, beliefs about justice, value orientations of various social groups and their dynamics, a role of trust in economic interactions, ethnic features in attitudes towards property, studies of entrepreneurial preferences/expectations, personal material self-sufficiency, attitude to innovation, religious ethics of economy, etc. (I.V. Andreeva, O. S. Deineka, T.V. Drobysheva, A.L. Zhuravlev, A.N. Lebedev, N.M. Lebedeva, V.P. Pozniakov, A.D. Karnyshev, D.A. Kitova, A.B. Kupreichenko, A.N. Tatarko, V.A. Khashchenko, E.V. Shorokhova and others).

Table 1. Analysis of dynamics in increasing popularity of "economy" as a search term in the condition of pandemic in Google Search among the users from three countries, 01.01.2020 - 31.07.2020

\begin{tabular}{|c|c|c|c|c|c|c|c|}
\hline Russia & & & Japan & & & USA & \\
\hline RISING & translation & & RISING & translation & & RISING & \\
\hline $\begin{array}{c}\text { экономика родного } \\
\text { края }\end{array}$ & $\begin{array}{c}\text { economy of the } \\
\text { native land }\end{array}$ & Super 1 & $\begin{array}{c}\text { 経済 コロ } \\
\text { ナ }\end{array}$ & $\begin{array}{l}\text { economy } \\
\text { corona }\end{array}$ & Super & $\begin{array}{l}\text { coronavirus } \\
\text { economy }\end{array}$ & Super \\
\hline $\begin{array}{l}\text { как обмен решает } \\
\text { задачи экономики }\end{array}$ & $\begin{array}{c}\text { how exchange } \\
\text { solves the } \\
\text { economic tasks }\end{array}$ & Super & $\begin{array}{c}\text { コロナ ウ } \\
\text { イルス 経 } \\
\text { 済 }\end{array}$ & $\begin{array}{c}\text { economy } \\
\text { coronavirus }\end{array}$ & Super & $\begin{array}{c}\text { covid } \\
\text { economy }\end{array}$ & Super \\
\hline $\begin{array}{c}\text { экономический } \\
\text { кризис } 2020\end{array}$ & $\begin{array}{l}\text { economic crisis } \\
2020\end{array}$ & Super & $\begin{array}{l}\text { コロナ 対 } \\
\text { 策 }\end{array}$ & $\begin{array}{l}\text { counter- } \\
\text { coronavirus } \\
\text { measures }\end{array}$ & Super & $\begin{array}{c}\text { reopen } \\
\text { economy }\end{array}$ & Super \\
\hline $\begin{array}{c}\text { экономика и ее роль } \\
\text { в жизни общества }\end{array}$ & $\begin{array}{l}\text { economy and its } \\
\text { role in a society }\end{array}$ & Super & $\begin{array}{c}\text { 経済 対策 } \\
\text { コロナ }\end{array}$ & $\begin{array}{l}\text { economic } \\
\text { measures } \\
\text { corona }\end{array}$ & Super & $\begin{array}{c}\text { estimulo } \\
\text { economico } \\
\text { (Spanish) }\end{array}$ & Super \\
\hline $\begin{array}{c}\text { назови круг } \\
\text { экономических } \\
\text { проблем, } \\
\text { регулируемых } \\
\text { государством }\end{array}$ & $\begin{array}{l}\text { name a range of } \\
\text { economic issues } \\
\text { regulated by the } \\
\text { state }\end{array}$ & Super & $\begin{array}{c}\text { 日本 経済 } \\
\text { コロナ }\end{array}$ & $\begin{array}{l}\text { Japanese } \\
\text { economy } \\
\text { corona }\end{array}$ & Super & $\begin{array}{l}\text { economic } \\
\text { impact } \\
\text { payments }\end{array}$ & Super \\
\hline $\begin{array}{c}\text { в чем сложность } \\
\text { экономического } \\
\text { выбора }\end{array}$ & $\begin{array}{l}\text { what is the nature } \\
\text { of complexity of } \\
\text { economic choice }\end{array}$ & Super & $\begin{array}{c}\text { 新型 コロ } \\
\text { ナ 経済 }\end{array}$ & $\begin{array}{c}\text { new variant of } \\
\text { corona } \\
\text { economy }\end{array}$ & Super & $\begin{array}{l}\text { us economy } \\
\text { coronavirus }\end{array}$ & Super \\
\hline $\begin{array}{c}\text { экономические и } \\
\text { социальные }\end{array}$ & $\begin{array}{l}\text { economic and } \\
\text { social }\end{array}$ & Super & $\begin{array}{l}\text { コロナ 経 } \\
\text { 済 影響 }\end{array}$ & $\begin{array}{l}\text { economic } \\
\text { effect of corona }\end{array}$ & Super & $\begin{array}{l}\text { reopening } \\
\text { economy }\end{array}$ & Super \\
\hline
\end{tabular}

\footnotetext{
${ }^{1}$ Superpopularity
} 


последствия
безработицы
какие способы
воздействия на
экономику может
использовать
государство
фритредерство

в чем заключается роль производства в экономике

что такое командная экономика

департамент экономического развития

виды экономической деятельности types of economic activity

тест по обществознанию consequences of unemployment

what measures may be used by the state to influence the economy free trading

$5000 \%$ 新型コロ new variant of Super coronavirus Super ナウイル coronavirus economic ス経済 economy impact

$450 \%$ コロナ世 corona global Super irs economic Super 界経済 economy impact payment

what is the role of $3450 \%$ 新型 コロ production in

ナ 経済対 策

counter- Super economic Super coronovirus impact economy economic payment measures

what is command $3450 \%$

コロナウ economic Super segundo Super economy

イルス経 measures to 済対策 $\begin{gathered}\text { fight } \\ \text { coronavirus }\end{gathered}$

Department of
Economic
Development

$700 \%$ economic

コロナウ イルス経 consequences 済影響 of coronavirus

Super economic Super impact payment card economico types of economity
activity mic $400 \%$ コロナ緊 急経済対 corona Super irs economic Super 策 economic payments measures social studies test $300 \%$ コロナ経ｅconomic Super economic Super 済支援 support corona impact payments check фазы экономического stages of economic $170 \%$ アメリカ corona USA Super economic Super цикла cycle coronavirus

\section{Problem Statement}

Analysis of many economic phenomena increases the interest of scientific community to psychological make-up of population as a resource for macroeconomic development of a society, however the nature of psychological factors directly influencing the nation's economy is still understudied.

\section{Research Questions}

At the current stage of development of psychology in Russia, studies of cross-cultural differences in economic processes are starting to form an independent scientific field. Among the trends in analysis of economic phenomena, one may see an increased scientific interest to psychological make-up of the population as a resource for economic development: Attention of researchers is turned to search of 
psychological factors directly influencing the national economy. In particular, Iasin (2003) notes that an efficient modernization of the Russian economy would require changing the value system of the population, which would allow turning to "modernization from the bottom up", being a more efficient variant of economic development. A necessity to form innovative setup has been also stated by Sukharev (2017), who also notes that a lack of aspirations for change among the Russians is limiting the social and economic development of Russia. Nevertheless, Lebedeva (2010) in her studies notes that while the effect of accelerated development of the Chinese economy is well-known globally, the attitude to change among Russian and Canadian students is higher than that of the Chinese students. Thus, as of now, this scientific field has more questions than answers (Gorshkov, 2013; Kitova, 2020).

\section{Purpose of the Study}

The purpose of the study is to analyze structural and substantial characteristics and dynamics of economy-related Interned search queries during the pandemic.

\section{Research Methods}

It is assumed that in the conditions of uncertainty caused by the pandemic, there will be an increased interest to economic factors of life among search system users, inevitably reflected in the nature of their Internet search queries. This interest is analyzed as a psychological phenomenon that influences the nature of personal social activity, is determined by specific motifs, characterized by cognitive awareness and stability, aimed at specific objects, relevant to a specific goal and may be studied with praximetric methods through analysis of products of activity (completed search queries) (Zhuravlev \& Kitova, 2019). Analysis of structural and content characteristics and dynamics of economy-related Internet queries in the context of pandemics covered three countries characterized with different historical and psychological types of economic development (Russia, USA and Japan). The object of the research is users of Internet search engines; the subject of the research is the content of search queries including the word "economy"

The work is based on using data obtained from Google Trends web application, functionality of which includes obtaining data on impression share and collocations related to a given word ("business news", "Russian economy", "work from home", etc.). Most popular concomitant words are given 100 points by Google, those less popular are getting less respectively. Queries that demonstrate significant growth with respect to a previous period are marked as "popular", while those where user activity has gone up very much are marked as "superpopular".

\section{Findings}

The data arranged in accordance with the described principles are given in Table 1. Several conclusions may be made from data in Table 1. First, in all three countries queries with the word 'economy' are super popular, but the nature of interest varies between countries: For instance, in Russia, the top result is "economics of the native land", while in Japan and the USA, the interest is focusing on the effects of the COVID-19 pandemic on the economy. In Russia, the interest to economics has an abstract theorizing nature, search queries include such terms as "economy and its role in a society", "range of economic issues 
regulated by the state", "role of production in economy", "tests on social studies", etc. Such specifics of queries suggests that the queries were composed by students. This suggestion is further supported by the fact that when the summer and thus summer school holidays start, the numbers of economy-related searches from Russian in both Yandex and Google reduce significantly (See in Table 2).

Table 2. Analysis of dynamics in increasing popularity of "economy" as a search term in the condition of pandemic in Google Search among the users from three countries, 01.01.2020 - 31.07.2020

\begin{tabular}{|c|c|c|c|c|c|c|c|}
\hline Russia & & & Japan & & & USA & \\
\hline RISING & translation & & RISING & translation & & RISING & \\
\hline $\begin{array}{c}\text { экономика родного } \\
\text { края }\end{array}$ & $\begin{array}{l}\text { economy of the } \\
\text { native land }\end{array}$ & Super2 & $\begin{array}{c}\text { 経済 コロ } \\
\text { ナ }\end{array}$ & $\begin{array}{l}\text { economy } \\
\text { corona }\end{array}$ & Super & $\begin{array}{l}\text { coronavirus } \\
\text { economy }\end{array}$ & Super \\
\hline $\begin{array}{l}\text { как обмен решает } \\
\text { задачи экономики }\end{array}$ & $\begin{array}{l}\text { how exchange } \\
\text { solves the } \\
\text { economic tasks }\end{array}$ & Super & $\begin{array}{l}\text { コロナ ウ } \\
\text { イルス 経 } \\
\text { 済 }\end{array}$ & $\begin{array}{l}\text { economy } \\
\text { coronavirus }\end{array}$ & Super & $\begin{array}{c}\text { covid } \\
\text { economy }\end{array}$ & Super \\
\hline $\begin{array}{c}\text { экономический } \\
\text { кризис } 2020\end{array}$ & $\begin{array}{l}\text { economic crisis } \\
2020\end{array}$ & Super & $\begin{array}{l}\text { コロナ 対 } \\
\text { 策 }\end{array}$ & $\begin{array}{l}\text { counter- } \\
\text { coronavirus } \\
\text { measures }\end{array}$ & Super & $\begin{array}{c}\text { reopen } \\
\text { economy }\end{array}$ & Super \\
\hline $\begin{array}{c}\text { экономика и ее роль } \\
\text { в жизни общества }\end{array}$ & $\begin{array}{l}\text { economy and its } \\
\text { role in a society }\end{array}$ & Super & $\begin{array}{l}\text { 経済 対策 } \\
\text { コロナ }\end{array}$ & $\begin{array}{l}\text { economic } \\
\text { measures } \\
\text { corona }\end{array}$ & Super & $\begin{array}{l}\text { estimulo } \\
\text { economico } \\
\text { (Spanish) }\end{array}$ & Super \\
\hline $\begin{array}{c}\text { назови круг } \\
\text { экономических } \\
\text { проблем, } \\
\text { регулируемых } \\
\text { государством }\end{array}$ & $\begin{array}{l}\text { name a range of } \\
\text { economic issues } \\
\text { regulated by the } \\
\text { state }\end{array}$ & Super & $\begin{array}{c}\text { 日本 経済 } \\
\text { コロナ }\end{array}$ & $\begin{array}{l}\text { Japanese } \\
\text { economy } \\
\text { corona }\end{array}$ & Super & $\begin{array}{l}\text { economic } \\
\text { impact } \\
\text { payments }\end{array}$ & Super \\
\hline $\begin{array}{c}\text { в чем сложность } \\
\text { экономического } \\
\text { выбора }\end{array}$ & $\begin{array}{l}\text { what is the nature } \\
\text { of complexity of } \\
\text { economic choice }\end{array}$ & Super & $\begin{array}{c}\text { 新型 コロ } \\
\text { ナ 経済 }\end{array}$ & $\begin{array}{c}\text { new variant of } \\
\text { corona } \\
\text { economy }\end{array}$ & Super & $\begin{array}{l}\text { us economy } \\
\text { coronavirus }\end{array}$ & Super \\
\hline $\begin{array}{c}\text { экономические и } \\
\text { социальные } \\
\text { последствия } \\
\text { безработицы }\end{array}$ & $\begin{array}{l}\text { economic and } \\
\text { social } \\
\text { consequences of } \\
\text { unemployment }\end{array}$ & Super & $\begin{array}{l}\text { コロナ 経 } \\
\text { 済 影響 }\end{array}$ & $\begin{array}{l}\text { economic } \\
\text { effect of corona }\end{array}$ & Super & $\begin{array}{l}\text { reopening } \\
\text { economy }\end{array}$ & Super \\
\hline $\begin{array}{c}\text { какие способы } \\
\text { воздействия на } \\
\text { экономику может } \\
\text { использовать } \\
\text { государство }\end{array}$ & $\begin{array}{l}\text { what measures } \\
\text { may be used by } \\
\text { the state to } \\
\text { influence the } \\
\text { economy }\end{array}$ & $5000 \%$ & $\begin{array}{l}\text { 新型 コロ } \\
\text { ナ ウイル } \\
\text { ス 経済 }\end{array}$ & $\begin{array}{c}\text { new variant of } \\
\text { coronavirus } \\
\text { economy }\end{array}$ & Super & $\begin{array}{l}\text { coronavirus } \\
\text { economic } \\
\text { impact }\end{array}$ & Super \\
\hline фритредерство & free trading & $3450 \%$ & $\begin{array}{l}\text { コロナ世 } \\
\text { 界経済 }\end{array}$ & $\begin{array}{c}\text { corona global } \\
\text { economy }\end{array}$ & Super & $\begin{array}{l}\text { irs economic } \\
\text { impact } \\
\text { payment }\end{array}$ & Super \\
\hline
\end{tabular}

\footnotetext{
${ }^{2}$ Superpopularity
} 


\begin{tabular}{|c|c|c|c|c|c|c|c|}
\hline $\begin{array}{c}\text { в чем заключается } \\
\text { роль производства в } \\
\text { экономике }\end{array}$ & $\begin{array}{c}\text { what is the role of } \\
\text { production in } \\
\text { economy }\end{array}$ & & $\begin{array}{l}\text { 新型 コロ } \\
\text { ナ 経済 対 } \\
\text { 策 }\end{array}$ & $\begin{array}{l}\text { counter- } \\
\text { coronovirus } \\
\text { economic } \\
\text { measures }\end{array}$ & Super & $\begin{array}{l}\text { economic } \\
\text { impact } \\
\text { payment }\end{array}$ & Super \\
\hline $\begin{array}{c}\text { что такое командная } \\
\text { экономика }\end{array}$ & $\begin{array}{l}\text { what is command } \\
\text { economy }\end{array}$ & $3450 \%$ & $\begin{array}{l}\text { コロナウ } \\
\text { イルス 経 } \\
\text { 済 対策 }\end{array}$ & $\begin{array}{l}\text { economic } \\
\text { measures to } \\
\text { fight } \\
\text { coronavirus }\end{array}$ & Super & $\begin{array}{l}\text { segundo } \\
\text { estimulo } \\
\text { economico }\end{array}$ & Super \\
\hline $\begin{array}{c}\text { департамент } \\
\text { экономического } \\
\text { развития }\end{array}$ & $\begin{array}{l}\text { Department of } \\
\text { Economic } \\
\text { Development }\end{array}$ & $700 \%$ & $\begin{array}{l}\text { コロナ ウ } \\
\text { イルス 経 } \\
\text { 済影響 }\end{array}$ & $\begin{array}{c}\text { economic } \\
\text { consequences } \\
\text { of coronavirus }\end{array}$ & Super & $\begin{array}{l}\text { economic } \\
\text { impact } \\
\text { payment card }\end{array}$ & Super \\
\hline $\begin{array}{c}\text { виды экономической } \\
\text { деятельности types of } \\
\text { economic activity }\end{array}$ & $\begin{array}{l}\text { types of economic } \\
\text { activity }\end{array}$ & $400 \%$ & $\begin{array}{l}\text { コロナ 緊 } \\
\text { 急 経済 対 } \\
\text { 策 }\end{array}$ & $\begin{array}{c}\text { corona } \\
\text { emergency } \\
\text { economic } \\
\text { measures }\end{array}$ & Super & $\begin{array}{l}\text { irs economic } \\
\text { impact } \\
\text { payments }\end{array}$ & Super \\
\hline $\begin{array}{c}\text { тест по } \\
\text { обществознанию }\end{array}$ & social studies test & $300 \%$ & $\begin{array}{l}\text { コロナ 経 } \\
\text { 済 支援 }\end{array}$ & $\begin{array}{c}\text { economic } \\
\text { support corona }\end{array}$ & Super & $\begin{array}{l}\text { economic } \\
\text { impact } \\
\text { payments } \\
\text { check }\end{array}$ & Super \\
\hline $\begin{array}{c}\text { фазы экономического } \\
\text { цикла }\end{array}$ & $\begin{array}{c}\text { stages of economic } \\
\text { cycle }\end{array}$ & $170 \%$ & $\begin{array}{c}\text { アメリカ } \\
\text { コロナ }\end{array}$ & corona USA & Super & $\begin{array}{l}\text { economic } \\
\text { impact of } \\
\text { coronavirus }\end{array}$ & Super \\
\hline
\end{tabular}

In Japan, all 15 leading economy-related queries are also pandemic-related. Internet users are interested in the state of economy in the context of the pandemic in Japan and abroad, possible countercrisis measures and predicted consequences. Americans also show a strong interest to the influence that the pandemic exerts on the economy: all 15 leading economy-related queries are also pandemic-related Of them, 10 are related to the influence that the pandemic has on the US economy and possible reactions to the crisis, and a 5 are related to the American stimulus package.

General balance of the analysis results has shown that the influence of pandemic on the economy is interesting to about $5 \%$ of Russian Internet users, while among Japanese and American users this indicator approaches $100 \%$.

In order to study the economy-related queries in more depth, statistics of queries from the Yandex Search was additionally studied. This service also allows studying a given word (economy) in combinations with related words, that is, a collocation is analyzed as a whole and linked to a number of post impressions per month. It has been revealed that there were 4,478,557 queries containing the word "экономика" (economy) in Russia in the period from 28.03.2021 to 28.04.2021.

Figure 1 shows those items that has got more than 100,000 queries. As it is evident from the figure, the results correlate with those obtained from analysis of Google data: the queried terms reflect theoretical categories studied in schools, colleges and universities. Thus, it is possible to state that the interest to dayto-day economic activities is clearly underrepresented in popular queries in general. It is important to make another clarification: while only a fraction of college and university students are in economics-related 
courses, all the Russian school pupils have to study the subject of Russian economy that includes a regional component titled Economy of the Native Land, that is why this search terms are more popular than others.

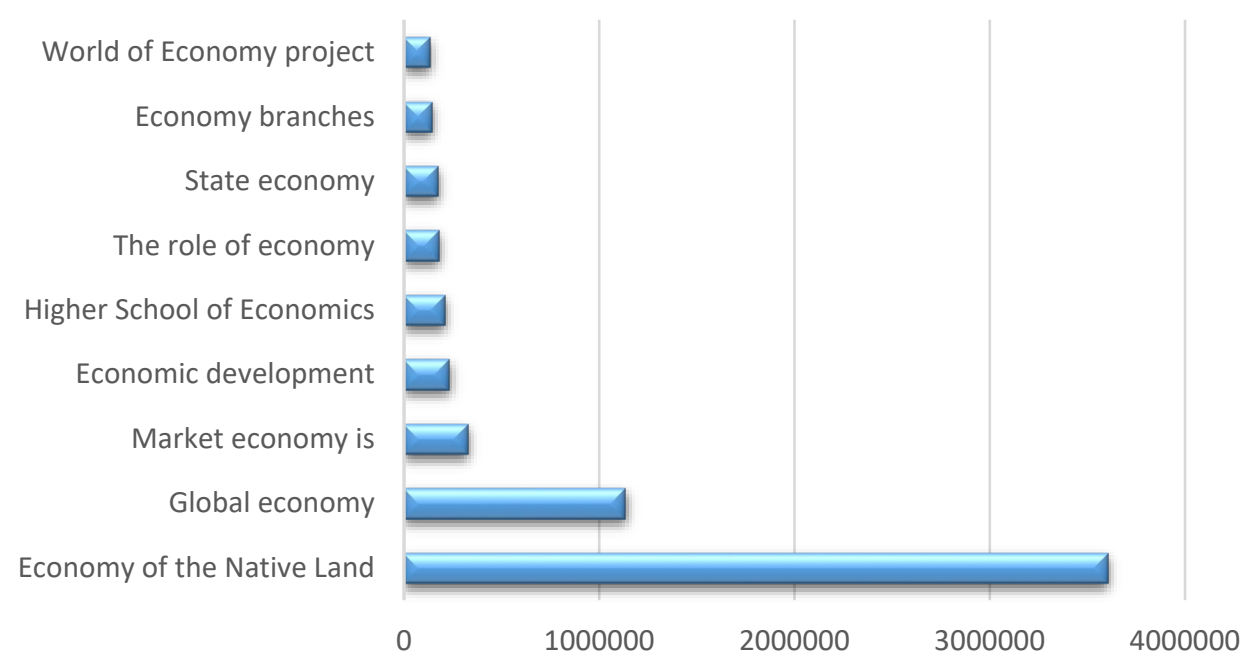

Figure 1. Distribution of interest to information on the state of Russian economy in the condition of the pandemic as seen from search queries in Yandex Search from 01.01.2020 to 31.07.2020 (in thousands.)

Summarizing the obtained results paints the following picture. Russian citizens demonstrate primarily abstract theorizing interest to economy, unrelated to the pandemic; the most part of which correlates with the curricula of secondary school and professional education institutions.

In Japan, the interest to economy is characterized by both theoretic and practical aspects, as Japanese are interested the state of their national economy and global issues in economic development in the context of the pandemic. Their interest is related to general measures to overcoming the crisis in the country and the world as a whole, as well as with possibilities to obtain support to business, whether currently or in a future. General interest in the economy is completely determined by the pandemic situation, which is evident from the most popular search queries that include the word "economy": 15 out of the top 15 items are related to pandemic impact.

In the USA, as evident from the most popular queries, the interest to the pandemic and its influence onto economic processes is also a common phenomenon. At the same time, attention of Americans focuses exclusively on internal American problems and also shows an interest to specific measures of popular social and economic support, which is untypical of both Japanese and Russian Interned users. That is why Americans show similar level of interest to the economic effects of the pandemic and the economic stimulus (search queries involving a card, IRS, checks, etc.).

\section{Conclusion}

Interest to economic processes in the condition of the rising pandemic is common all over the world, but in different countries there are different specifics. Russian citizens demonstrate an interest to abstract theoretical economic problem, unrelated to the coronavirus pandemic. In the USA and Japan, most interest 
to economy is focused on pandemic-related topics, but with national specifics Japanese citizens are interest in countermeasures both in their own country and abroad, while Americans are interested exclusively in what happens in their country and additionally demonstrate a clear orientation to the measures of state support of citizens during the pandemic.

The obtained data reflects macropsychological state of the modern Russian society in comparison with representatives of countries with a different sociocultural specific of development. It forms a foundation for understanding specifics of population attitudes to economic factors, both in the conditions of uncertainty due to the pandemic and in identification of psychological factors in daily life of a person, which taken together over time influence the socioeconomic development of a the society. The obtained results may be interesting within the framework of fundamental research in the field of psychology of uncertainly, economic psychology, social psychology and a number of other scientific fields and domains (economics, sociology, philosophy, etc.).

\section{Acknowledgments}

This research has been conducted with the financial support from the Russian Foundation for Basic Research (RFBR, under the project no. 21-18-00541.

\section{References}

Fukuyama, F. (2004). Trust: Social Virtues and a Way to Prosperity. AST: ZAO NPP Ermak.

Gorshkov, M. K. (2013). Non-economic factors of economic growth: untapped reserves. Humanities. Annals of the Financial University, 10, 33.

Iasin, E. G. (2003). Modernization of Economy and a System of Values. Higher School of Economics.

Inglehart, R., \& Welzel, C. (2005). Cultural Change and Democracy: The Human Development Sequence. Cambridge University Press.

Kitova, D. A. (2020). Microeconomic psychology of a life actor. Publish House of the Institute of Psychology of the Russian Academy of Sciences.

Lebedeva, N. M. (2010). Values and attitude to innovation among Russian, Canadian and Chinese students. Psychology in Economy and Management, 6, 59.

Sukharev, A. V. (2017). Development of a Russian mentality. Publish House of the Institute of Psychology of the Russian Academy of Sciences.

Zhuravlev, A. L. (1998). Influence of socio-psychological and socio-economic phenomena in a changing society. Social and Psychological Dynamics in the Context of Economic Changes, 11-37.

Zhuravlev, A. L., \& Kitova, D. A. (2019). Social and psychological factors of economic development of the Russian society in the context of digital technologies. Institute of Psychology of the Russian Academy of Sciences. Social and Economic Psychology, 16, 6. 